\section{5. 䊅論}

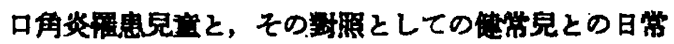

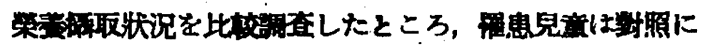
比しトリブトフフン皮びナイフシン触取早が少いことが

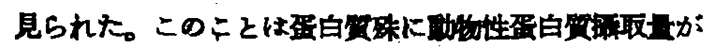
首各において少いことと咸連しているのである。前報に あ流べたよりに，之等兒童の口角炎に對してはナイフシ

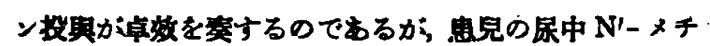

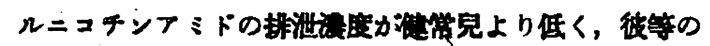
ナイフシン代爵力低水準にあると考えられる。

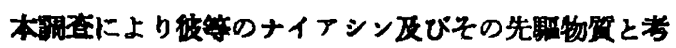
えられているトリプトフフンの日常取嘬沙いことを

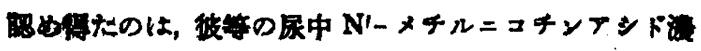

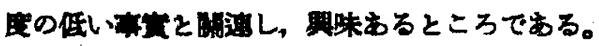

\section{x .}

1. 薄田, ヒタミン 4:16. 1948.

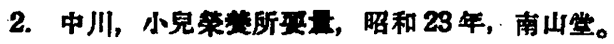

3. 中川, ヒタミン $2: 236.1950$.

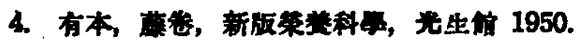

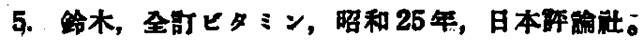

6. 伊藤文男, ヒタะン $4: 275.1951$.

7. The Amino Acid Composition of Proteins and Foods by Richard J. Block. PH.D. and Diana Bolling B.S. 1951.

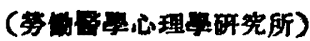

\title{
白米の榮養强化に關子る研究 \\ Studies on the Enrichment of white rice
}

\author{
第4 報 外米の强化に就て \\ Part IV The enrichment of imported rice
}

(昭和 27 年 7 月 1 日受理)

櫻 井 純 - .
(Jun-ichi Sakurai)

等者は先に女米の Parboiling の方法として交米を水

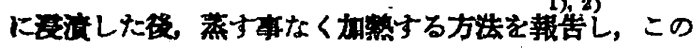

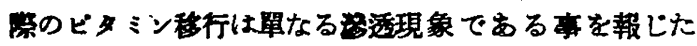

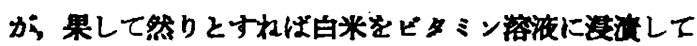

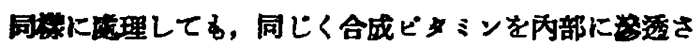

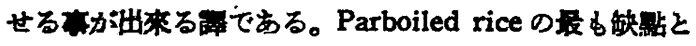

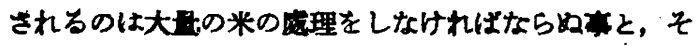
の琛作により稍曼具がつくひであるが、白米に合成ビタ

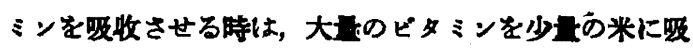
收させて，之を大量の米に混合配給する事油淶來るの で, 容易に大四の崛化が油來且つ味す全然果味を感ぜし める市がない。

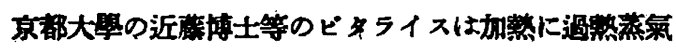

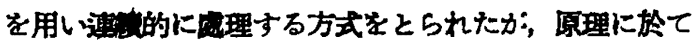
は全く同一である。

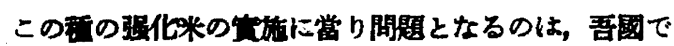

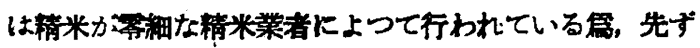
玄米を棈米業者の手により精白し，之を集めて强化米を

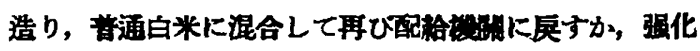

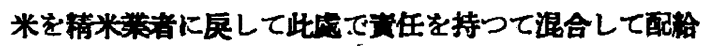
するかしなければならない。然るに外米は精白米として

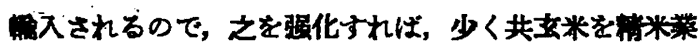
者に渡して瞥白させてから文㹕めるといら操作等は省く

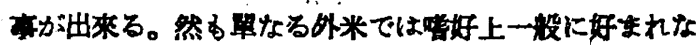

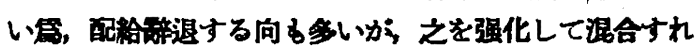

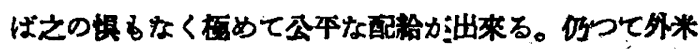

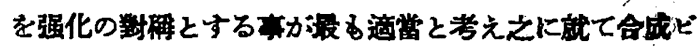
タミンを强化する諴会を行つた。

\section{貝 驗の 部}

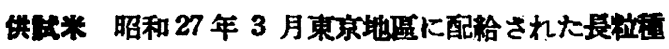
シャム米, 品重不群。

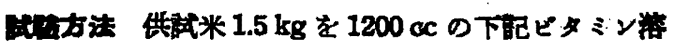

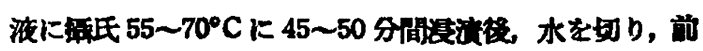

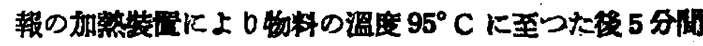
加熱虎理し（全加繁時間 23〜25 分) 次で静かに乾燥し 
て水分 13\%以下とし，得た成品並に行程间の夫の各部の ビタミンをバームチントを用いるチォクロム法により湖 定して，成品に移行したビタミン，淘洗に上り失れれる ビタミン，製造行程間に失かれるビタミンを測定した。 (下国照)

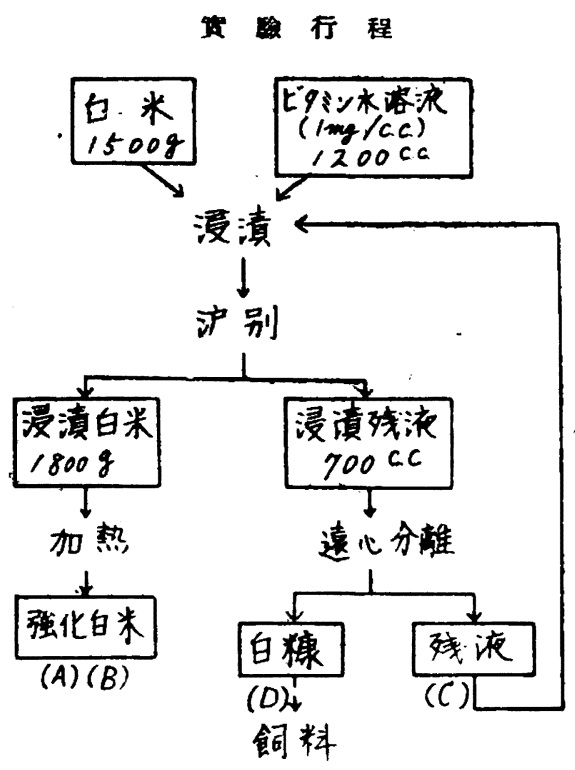

(A) 成品中のビタミン

(B) 成品跌後のビタミン

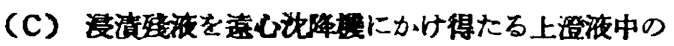
ビタミン，那ち夫の浸瀆に用いられるビタミン。 (D) (C)により得られた轧嵖中のビタミン。 之は境理により生ずる損失と考えらんるるのでする が乾燥して铜料の强化等に用いられる。

Exp. 273 に於ては一部シェラククによる被覆を施し，

第1表 变淡洨の調製

\begin{tabular}{|c|c|c|c|c|}
\hline 英驗番㴲 & ヒタミン碾度 & 閣 & 製 & 法 \\
\hline 271 & $1 \mathrm{mg} / \mathrm{cc}$ & \multicolumn{3}{|c|}{ 水溶洨 } \\
\hline 272 & " & \multicolumn{3}{|c|}{$\begin{array}{l}\text { 同上, 第 } 1 \text { 回津淡残液に } \\
530 \mathrm{cc} の \text { 新しい液㭪充 }\end{array}$} \\
\hline 273 & $4 \mathrm{mg} / \mathrm{cc}$ & \multicolumn{3}{|c|}{ 水渚做 } \\
\hline 274 & $1 \mathrm{mg} / \mathrm{cc}$ & \multicolumn{3}{|c|}{ 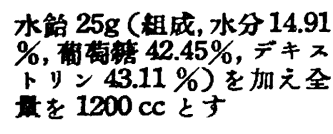 } \\
\hline 275 & $1 \mathrm{mg} / \mathrm{cc}$ & \multicolumn{3}{|c|}{$\begin{array}{l}\text { 全醖 } 12 \mathrm{~g} \text { を加え全是を } \\
1200 \text { と }\end{array}$} \\
\hline
\end{tabular}

被票しない場合と海洗の際のビタミンの損失を比較し，

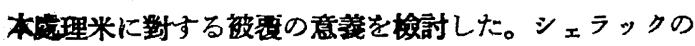
被覆は米 $400 \mathrm{gr}$ に對しシェラック $16 \mathrm{~g}$ を $50 \mathrm{cc}$ のーテ
ルに溶解し，米を coating machine 中に迴轉しながら シェラック溶液を加えて行つだ。ッラックの所要量は * $25 \mathrm{~kg}$ に對し1 kg である。

Exp. 274 は急激な乾燥により胴割を生ずる事を防ぐ 目的によりビタミンを蒲萄糖，デキストリン混液に洛解 し米を浸源した。淢萄糖，デキストリン混液は激粉を硫 酸で糖化した水飴（組成水分 $14.91 \%$ ，葡萄糖 $42.45 \%$ ， デキストリン $43.11 \%$ ） $25 \mathrm{~g}$ を $1200 \mathrm{cc}$ に溶解して用い た。即ち葡萄糖 $0.87 \%$ ，デキストリン $0.90 \%$ である。

Exp. 275 に於ては食愳に浸漬したが,之は前報の宽㹂

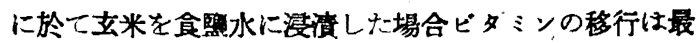
めよかつたので，この場合にも优つてみた。

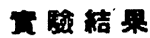

上逝の湘定結果を表示寸ると第 2 表の通りである。

第2 表 贸驗結 果

\begin{tabular}{|c|c|c|c|c|c|c|c|}
\hline \multirow{2}{*}{$\begin{array}{l}\text { 资駺 } \\
\text { 番號 }\end{array}$} & \multicolumn{2}{|c|}{ 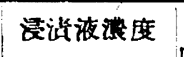 } & \multirow{2}{*}{ 及水散 } & \multicolumn{2}{|c|}{$\begin{array}{l}\text { 白米のjビタ } \\
\text { ミン合有期 }\end{array}$} & \multicolumn{2}{|c|}{ 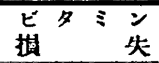 } \\
\hline & 浔谈前 & 浸瀢後 & & 海洗前沙 & 洸楼 & $\mathrm{mg}$ & 百分率 \\
\hline 271 & $\begin{array}{l}\gamma / \mathrm{cc} \\
1.000\end{array}$ & $\begin{array}{r}r / \mathrm{cc} \\
870\end{array}$ & 460 & $\begin{array}{c}\gamma / g \\
300\end{array}$ & $\begin{array}{l}\gamma / g \\
2907\end{array}$ & $\begin{array}{r}\mathrm{mg} \\
74 \sim 90\end{array}$ & $\begin{array}{l}\% \\
\sim 7\end{array}$ \\
\hline 272 & 1.000 & 945 & 480 & 330 & 280 & 36 & 3 \\
\hline $273 a$ & & $38 \mathrm{~s}$ & 47 & 1100 & 1000 & & \\
\hline $273 \mathrm{~b}$ & 40 & & 420 & 1100 & $1000\}$ & 30 & 3 \\
\hline 274 & 1.000 & 1.020 & 430 & 305 & 270 & - & - \\
\hline 27.5 & 1.000 & 1.040 & 500 & 280 & 260 & 一 & - \\
\hline
\end{tabular}

即ち，以上の結果により知り得たことは决の通りであ る。,

1）棈白米を $1 \mathrm{mg} / \mathrm{cc}$ の濃度の溚液に清けた場合，浸 清牫液中のビダミン莀度は殆んど警らず 280〜330 y/g のビタミン强化米を得た。

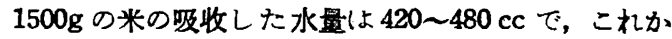
ら計算すれば $1500 \mathrm{~g}$ 中に 420 480mg の ビタ ミン $\mathrm{B}_{1}$, 郎ち1g 中 280 320yの $\mathrm{B}_{1}$ が含有されるわけでまつたく 㜈想と一致している。從來も Parboiling process に於 けるピタミンの移行は單なる染で，とくに吸着，その 他の現象ではないと報じたが，これによつてあ確認する ことが㳐來る。

2）本法の梯に加熱に上りピタミンを罘乳內部に浸透 させたすのは，特に被覆しないです淘珗による損失は極

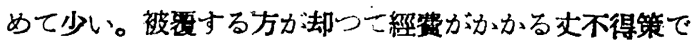
あるから被夏は不必要である。近藤博士等のビタライス

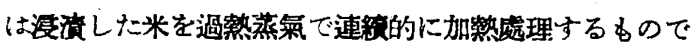
原理に於て全く變らないすのであるから，之に就てす同 じ事がいえるであろら。

3）浸溃によるビタミンの損失は 3〜7 \%であるが， これは乾燥して飼料の强化などに利用することか可能で ある。 


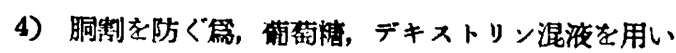
たが，この浱度の液では餘り效果は認められなかつた。

5）食孯の添加はビタミンの移行に何等好結果を與え なかつたが，之は玄米の場合に比し檢討を要する。

6）外米を强化米に加工する場合，加熱後も粘重にな らないので䡕めて處理し易く, 强化米の對稱として外米 は最す適栄である。

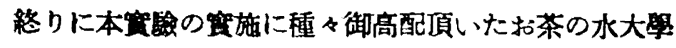
程堭長與数授, 分析の一部を御協力頂いた武田菜品株式
會社，東京工場及びシェラョク被室の笅を煩はした山冈

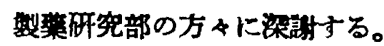

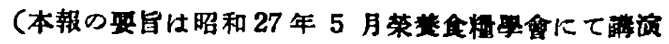
した。)

1）策娄と食精 4, 171 (1952).

2）榮媵と食桠 5, 7 (1952).

（御茶の水女子大學榮化）

\title{
2,3 海藻の消化吸收率に就て
}

On digestibility and abosorption rate of certain sea weeds

\author{
日本食の研究 (第8 報) \\ Studies on Japanese foods (Rep. 8)
}

(昭和 27 年 7 月 7 日受理)

木 村 典 雄
(Tsuneo Kimura)

日本人食生活の特徽は来食以外では哭肉括取量が少く 野荣と海產物の据取最が多い事といえるであろら。就中 海暴類は入手容易で目つ安價であるので日本人㓭食物中 重要な位圈を占めるすのである。然るにその吸收率は精 查せられたるのか沙い様である。郎ち僅かに大島氏の人 鳞, 澤村, 黑澤兩氏の小犬に就ての報告があるばかりで その緗果は头の第1菱にまとめられる。

第1表 昆布の吸收率 (滥村, 黑賟氏)

\begin{tabular}{|c|c|c|c|c|}
\hline & 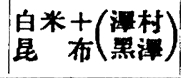 & 昆布(衹村 & 昆布鿖 & $\begin{array}{l}\text { わかめ㡵 } \\
\text { (大 }\end{array}$ \\
\hline 蛋白 & $74 \%$ & $\begin{array}{r}\% \\
17.572\end{array}$ & $\%$ & $\%$ \\
\hline 媘 & 25.042 & 8.198 & - & - \\
\hline 含水炭菜 & 93.531 & 一 & $55.0-75.2$ & 72.8 \\
\hline 灌 & - & - & $55.3-65.4$ & 2.8 \\
\hline te & 60.998 & 60.730 & - & - \\
\hline
\end{tabular}

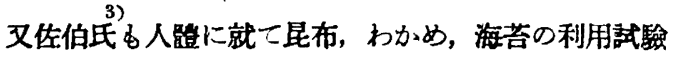
をやつて居るか遗堦ながらその吸收率を計算する事は出 來す，铃木民等は山羊に人體食用以外の海落たる「あま

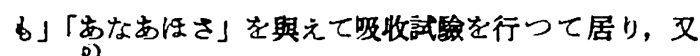
松浦氏等は最近海藻の 1 成分たるフルギン酸の榮羕偪を 研究報告して居るが、これ等は考にはなるが日常食に
する海落の消化吸收來を的確に知る資料とはならぬ，そ れで余は 2,3 代表的海藻に就て人體に於ける消化吸收 を检へたので報告する。材料としては北海道座の「まこ んぶ」Laminaria Japonica Aresch, 北海道產の「わか め」Undaria pinnatifida Suringar, 福岡市箱绮生の「浅 草海荅」Porphyra Tenera Kjellman Okamura et Ueda，を用いた。

\section{1. 昆布の消化吸收試驗}

副食物に用いタ昆布は「折昆布」として商品になつた。 あのでこれを1夜水に浸した後 4〜5 時間水で意つめた bのを砂糖及び然油で味を付け 2 日間白米と共に揤取さ せた。その量は 2 日間に尼布 $180 \mathrm{~g}$ ，白米 $1120 \mathrm{~g}$ であつ た。勿論每回々の $\frac{1}{6}$ 宛を給した。被检者は健康なる男子 5 名郎ち永松 (27 才, $53 \mathrm{~kg}, 165 \mathrm{~cm})$ ，太田 (29才, 55 $\mathrm{kg}, 158 \mathrm{~cm})$, 石田 $(27$ 才, $50 \mathrm{~kg}, 162 \mathrm{~cm})$, 田中 (28才 $57 \mathrm{~kg}, 172 \mathrm{~cm})$ ，村 $(29$ 才, $56 \mathrm{~kg}, 169 \mathrm{~cm})$ で何れる 當数室員である。屎採取には食前及び2 日間揤取後にカ ルミン又は炭末を用いて着色させた。分析方法は常法に よつた。

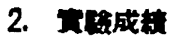

\section{1. 筑方法}

